\title{
Money Left on the Table: Generic Drug Prices in Canada
}

\section{Jeter l'argent par les fenêtres : le prix des médicaments génériques au Canada}

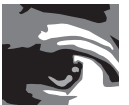 \\ MICHAEL R. LAW, PHD \\ Centre for Health Services and Policy Research \\ School of Population and Public Health \\ University of British Columbia \\ Vancouver, BC
}

\begin{abstract}
Background: Generic drugs are a major cost-saving opportunity for patients and drug plans.

While almost every province has reduced generic drug prices, we have no information on whether these new prices are internationally competitive. Therefore, I compared Canadian prices to those in two other countries.

Methods: I used 2009 data from the IMS Brogan Canadian CompuScript and PharmaStat databases and studied the 100 most frequently dispensed generic products in Ontario, which has Canada's lowest generic prices. I compared these prices to those in public drug programs in the United States and New Zealand that use tendering. Using these alternative prices, I calculated the potential savings in Ontario.

Results: Of the top 100 generic products, 82 were listed on an international formulary. In 90\% of cases, generic products were less expensive in other countries. If Ontario had obtained the lowest comparator price for these products, the annual public sector and overall drug expenditure savings would have been $\$ 129$ million and \$245 million, respectively. Further, the province could have publicly paid for all these generic drugs - both public and private - and saved $\$ 87$ million compared to current public sector expenditures.

Discussion: Even after recent reforms, generic drug prices in Canada remain high by international standards. I found that if Ontario had obtained commonly used generic drugs at international best prices, the province could have publicly paid for all generic drugs and lowered annual expenditures by nearly a quarter-billion dollars.
\end{abstract}




\section{Résumé}

Contexte: Les médicaments génériques constituent une excellente occasion d'épargne pour les patients et les régimes d'assurance médicaments. Bien que presque toutes les provinces aient réduit le prix des médicaments génériques, on ne sait pas si ces nouveaux prix sont concurrentiels à l'échelle internationale. J'ai donc comparé les prix au Canada avec ceux de deux autres pays. Méthode : J'ai utilisé les données de 2009 provenant des bases de données IMS Brogan Canadian CompuScript et PharmaStat et jai étudié les 100 produits génériques les plus fréquemment administrés en Ontario, province où le prix des médicaments génériques est le plus bas au Canada. J'ai comparé ces prix à ceux des programmes publics de médicaments aux États-Unis et en Nouvelle-Zélande, qui emploient la méthode des appels d’offres. À l'aide de ces coûts, j’ai calculé l'épargne que pourrait réaliser l'Ontario.

Résultats : Parmi les 100 produits génériques, 82 étaient inscrits sur une liste internationale. Dans $90 \%$ des cas, les produits génériques étaient moins chers dans d’autres pays. $\mathrm{Si}$, pour ces produits, l'Ontario avait obtenu les prix de comparaison les plus bas, l'épargne annuelle liée aux dépenses du secteur public et à l'ensemble des dépenses pour les médicaments aurait été de 129 millions de dollars et de 245 millions de dollars, respectivement. De plus, la province aurait pu payer tous ces médicaments génériques - tant publics que privés - avec les fonds publics et aurait épargné ainsi 87 millions de dollars par rapport aux dépenses actuelles du secteur public.

Discussion: Même après les récentes réformes, les prix des médicaments génériques demeurent élevés au Canada, par rapport aux normes internationales. J'ai découvert que si l'Ontario avait obtenu les principaux médicaments génériques aux meilleurs prix internationaux, elle aurait pu payer tous les médicaments génériques avec les fonds publics et aurait diminué les dépenses provinciales annuelles de près d'un quart de milliard de dollars.

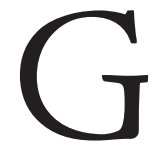
ENERIC DRUGS PROVIDE A MAJOR COST-SAVING OPPORTUNITY FOR PATIENTS AND drug plans by providing a similar therapeutic effect at a fraction of the cost (Kesselheim et al. 2008). In Canada, generic use is encouraged by both provincial drug plans and some private drug plans through the use of mandatory generic substitution rules and interchangeability provisions that allow them to be dispensed instead of more expensive brand-name alternatives (Secor Consulting 2010). As a result, generic drugs represented a majority of all the prescriptions dispensed in Canada in 2010 (IMS Brogan 2011). Additionally, generic drug use is poised to rise even higher as a suite of widely used medicines such as atorvastatin, clopidogrel and esomeprazole lose their patent protection (CIHI 2011).

Two factors determine the savings achieved through the use of generic drugs: (a) how often generics are dispensed relative to more expensive brand-name medicines and (b) the price of the generic version relative to the brand that it replaces. Historically, Canada has performed poorly on both factors. For example, only 57\% of the prescriptions dispensed in Canada in 2010 were for 
generics, compared to 78\% of prescriptions in the United States (IMS Brogan 2011; IMS Health 2011). Canadian generic manufacturers have claimed this difference led to $\$ 3$ billion in higher drug expenditures that year (Canadian Generic Pharmaceutical Association 2011).

At the same time, Canadians have historically paid some of the highest generic drug prices in the world (Competition Bureau Canada 2007, 2008; PMPRB 2006, 2010). Canadian prices have traditionally been set using a percentage of the equivalent brand-name price as a ceiling. Typically, these percentages ranged between $60 \%$ and $70 \%$ of the brand price, but recent and controversial changes have moved these price ceilings lower in almost every province, to a nationwide low of $25 \%$ in Ontario (Moulton 2011). This price level is now being cited as a benchmark for other provinces (Government of British Columbia 2012). However, there is little information on whether this arbitrary percentage-based approach results in internationally competitive prices.

Ensuring appropriate prices for generic drugs is important, as it has substantial financial implications for public drug plans, Canadian employers and the many Canadians who report being unable to afford their prescription drugs (Law and Kratzer 2012). Therefore, I compared these new Canadian prices to those paid by major public drug plans that use tendering in the United States and New Zealand, and determined the implications of these pricing differences for generic drug expenditures.

\section{Methods}

\section{Data sources}

This analysis used data on both dispensing and pricing. I obtained data on community pharmacy dispensing of prescription-only generic products in 2009 from two sources. I obtained data on the number of units (e.g., tablets or capsules) of each generic drug paid for by the public drug program in Ontario from the IMS Brogan PharmaStat database. From this data set, I extracted the top 100 generic products (e.g., simvastatin $10 \mathrm{mg}$ ) in terms of number of units paid for publicly in 2009. I matched these data to the IMS Brogan Canadian CompuScript database to obtain the total number of units of each generic drug dispensed by community pharmacies in the province, including those paid for by public insurance, private insurance and out-of-pocket payments. Both these data sets have been used extensively in prior research into drug use and costs in Canada (Guertin et al. 2011; Jackevicius et al. 2009; Morgan 2004; Morgan et al. 2003).

I matched these unit volumes to price information from three sources. Per-unit pricing data for the equivalent generic product were obtained from the following sources in 2011: the Ontario Drug Benefit Formulary, the Department of Veterans Affairs (VA) pharmaceutical price listings and New Zealand's Pharmac Schedule (Government of Ontario 2011; Pharmaceutical Management Agency 2011; Pharmacy Benefits Management Services 2012). These comparators were chosen because they both use more competitive tendering processes to set prices, and both make their prices publicly available (Board on Health Care Services 2000; New Zealand Pharmaceutical Management Agency 2011). Further, as both programs have used tendering for more than 10 years, they offer insight into the long-term prices available through the use of 
tendering procurement methods. As the international formularies both provided prices for packages of multiple pills, I divided the cost by the number of units to determine the lowest per-unit price. Because I compared per-unit formulary prices, my data did not include allowable pharmacy mark-up or dispensing fees. I converted formulary prices to Canadian dollars using average 2009 exchange rates (Bank of Canada 2011).

\section{Analysis}

My analysis focused on the top 100 most-dispensed generic products in Ontario's public drug program that were listed on one or both international formularies. In the event a drug was listed on both international formularies, I used the lower of the two prices. Drugs not listed on either international formulary were excluded from all estimates.

I analyzed the difference in total ingredient costs for generic drugs using three different scenarios. First, I calculated what the total ingredient costs would have been for the public sector under the current Ontario prices (25\% of the equivalent branded medicine). Then I estimated what the impact on public expenditures would have been in 2009 had Ontario attained the lowest comparator price I observed in the other formularies. Second, I performed the same comparison for the "total market" scenario, but used total unit volume in the entire province (both public and private) in place of the publicly paid unit volume. Finally, I estimated a "full public coverage" scenario, which calculated the net impact on the provincial budget of publicly paying for total utilization of these generic ingredients at the lowest comparator price. This comparison allowed me to estimate whether current public expenditures could pay for universal coverage of some generic medicines (Law and Morgan 2011).

\section{Sensitivity analyses}

To investigate the robustness of my findings, I also conducted three sensitivity analyses. First, I used exchange rates from both 2010 and 2011 instead of 2009 to investigate whether currency fluctuations would change my findings (Bank of Canada 2011). Second, I calculated more conservative savings estimates using (a) the higher price, rather than the lower, when both international prices were available, and (b) both international formularies independently. Third, I estimated total costs using $20 \%$ of the branded price rule (rather than $25 \%$ ), as this is the most recent approach undertaken in Ontario (to date only for the top 10 generic drugs).

\section{Results}

\section{Price differences}

In 2009, over 3 billion units of the top 100 generic drug products were dispensed in Ontario, and the public drug program paid for $56 \%$. Of the top 100 generic products, 82 were listed in one or both of the comparator countries (representing $82 \%$ of total unit volume). Of the 41 products listed in both Ontario and New Zealand, 38 were less expensive in New Zealand (93\%). Similarly, 69 of the 77 products listed both in Ontario and on the VA formulary were less expensive in the latter (90\%). 
Figure 1 shows the ratios in the prices between Ontario and the lowest price in either comparator for individual generic products. As shown in the figure, of the 82 drugs listed on the comparator formularies, 74 were less expensive in one or both other countries (90\%). On average, Ontario prices were nearly two times higher than those of the comparators. Further, 58 (71\%) products were more than twice as expensive in Canada, and 11 (13\%) were more than 10 times more expensive. The largest pricing discrepancy was for simvastatin $(10 \mathrm{mg})$, which was more than 30 times more expensive in Ontario. Of note, there were some exceptions. For example, generic oxazepam (15 mg and $30 \mathrm{mg}$ ), bisoprolol $(5 \mathrm{mg}$ and $10 \mathrm{mg}$ ) and risperidone $(0.25 \mathrm{mg})$ were less expensive in Ontario than in the comparator countries.

FIGURE 1. The frequency of different ratios in prices for the top 100 generic products between Ontario (set at 25\% of the equivalent brand-name medicine) and the best price for the same product in New Zealand's Pharmac Schedule or the US Department of Veterans Affairs price listings*

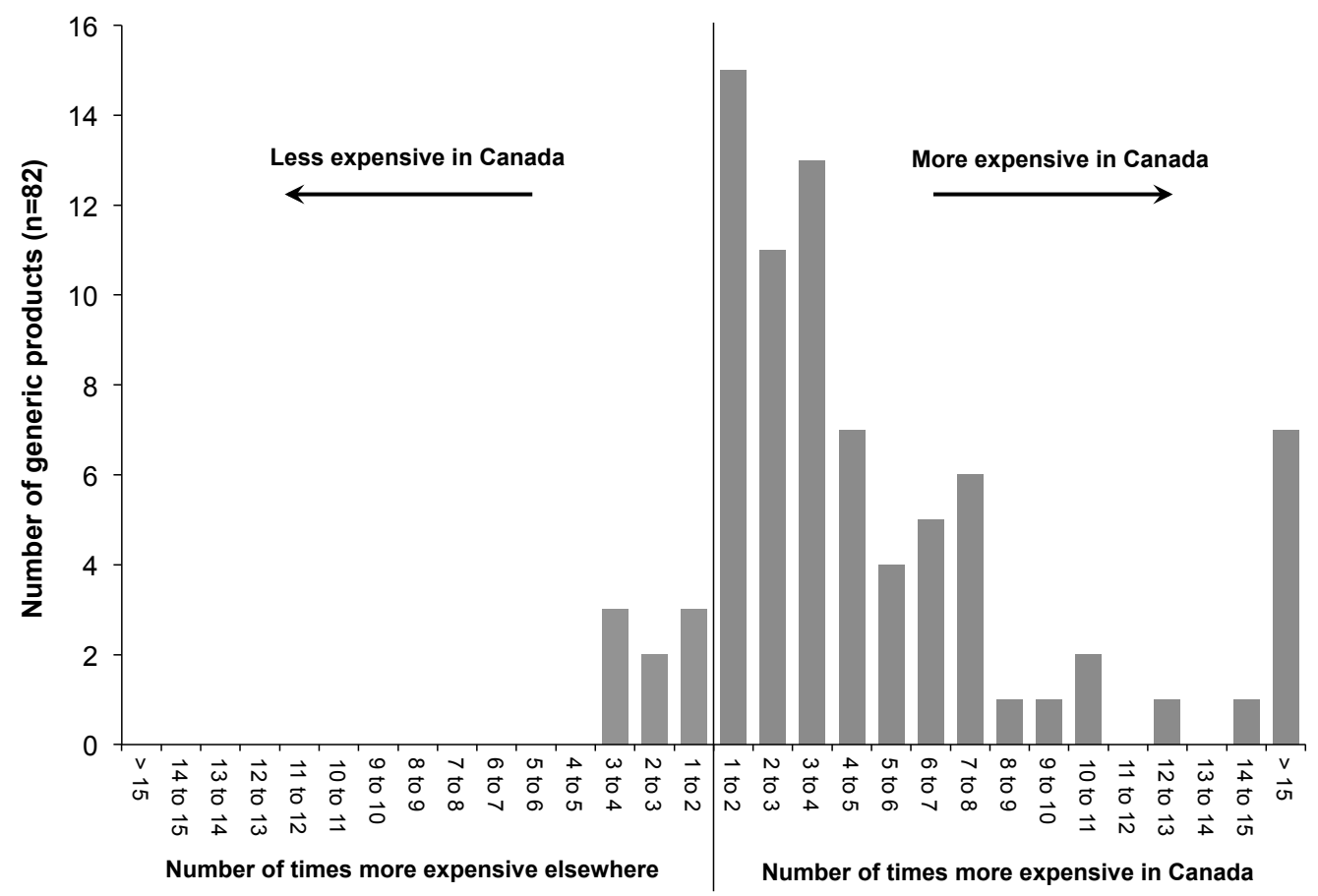

*Sources: Ontario Drug Benefit Formulary, the US Department of Veterans Affairs pharmaceutical price listings and the NZ Pharmaceutical Management Agency Schedule.

\section{PUBLIC SECTOR SCENARIO}

Based on dispensing volumes from 2009, the current Ontario prices (25\% of the brand-name price) would result in net ingredient costs for these 82 drugs of $\$ 190$ million (Table 1 ). In comparison, at the lowest comparator price, total public sector expenditures would have been $\$ 61$ million - a reduction of $\$ 129$ million (68\%). The largest single contribution to public savings would result from price changes to ramipril $(10 \mathrm{mg})$, which - if Ontario had purchased it at the international best price - would have resulted in a \$13-million reduction in expenditures. 


\section{TOTAL MARKET SCENARIO}

Similar to the results in the public sector scenario, the total cost for all generic purchases for the 82 generic drugs I studied would have been significantly lower had international best prices been used. While total generic ingredient costs would have been $\$ 347$ million at Ontario's $25 \%$ prices, they would have been $\$ 103$ million at the international best price - a reduction of $\$ 245$ million (71\%).

\section{FULL PUBLIC COVERAGE SCENARIO}

Table 1 shows the top 10 drugs in terms of savings from the full public coverage scenario. As shown in the table, full public coverage would have cost $\$ 61$ million less than just public expenditures under Ontario's current $25 \%$ prices for these 10 drugs alone, and reduced expenditures by $\$ 87$ million across all 82 drugs. Of note, I found that there were 30 different generic products for which the public savings under the full public coverage scenario would have saved more than $\$ 1$ million.

TABLE 1. The top 10 generic drugs in Ontario in 2009 in terms of their potential savings, using international prices rather than prices based on $25 \%$ of the brand-name equivalent under full public coverage. All prices are presented in Canadian currency and were converted using 2009 average exchange rates*

\begin{tabular}{|c|c|c|c|c|c|c|c|c|c|c|}
\hline \multirow[b]{2}{*}{ Ingredient } & \multirow[b]{2}{*}{ Dose } & \multicolumn{2}{|c|}{ Price Comparison } & \multicolumn{3}{|c|}{ Public Sector Scenario } & \multicolumn{3}{|c|}{ Total Market Scenario } & \multirow{2}{*}{$\begin{array}{c}\text { Full Public } \\
\text { Coverage } \\
\text { Scenario } \\
\begin{array}{c}\text { Potential } \\
\text { full coverag } \\
\text { savings }\end{array}\end{array}$} \\
\hline & & $\begin{array}{l}\text { Ontario } \\
\text { price at } \\
25 \% \\
\text { brand }(\phi)\end{array}$ & $\begin{array}{l}\text { Best int'l } \\
\text { price } \\
\text { (CADф) }\end{array}$ & $\begin{array}{l}\text { Public cost } \\
\text { at Ontario } \\
25 \% \text { price }\end{array}$ & $\begin{array}{l}\text { Public cost } \\
\text { at best } \\
\text { int'l price }\end{array}$ & $\begin{array}{c}\text { Potential } \\
\text { public savings }\end{array}$ & $\begin{array}{l}\text { Total cost } \\
\text { at Ontario } \\
25 \% \text { price }\end{array}$ & $\begin{array}{l}\text { Total cost } \\
\text { at best } \\
\text { int'l price }\end{array}$ & $\begin{array}{l}\text { Potential } \\
\text { total } \\
\text { savings }\end{array}$ & \\
\hline ramipril & 10 mg & 25.33 & 5.01 & $\$ 16,092,690$ & $\$ 3,185,044$ & $\$ 12,907,646$ & $\$ 26,191,298$ & $\$ 5,183,747$ & $\$ 21,007,551$ & $\$ 10,908,943$ \\
\hline metformin & $500 \mathrm{mg}$ & 5.87 & 1.16 & $\$ 14,3 \mid 8,039$ & $\$ 2,838,795$ & $\$ 11,479,244$ & $\$ 25,958,960$ & $\$ 5,146,806$ & $\$ 20,812,154$ & $\$ 9,171,233$ \\
\hline citalopram & 20 mg & 33.29 & 3.24 & $\$ 9,724,758$ & $\$ 945,557$ & $\$ 8,779,201$ & $\$ 20,431,137$ & $\$ 1,986,558$ & $\$ 18,444,578$ & $\$ 7,738,199$ \\
\hline simvastatin & 20 mg & 62.51 & 2.40 & $\$ 6,728,966$ & $\$ 258,074$ & $\$ 6,470,892$ & $\$ 13,000,270$ & $\$ 498,595$ & $\$ 12,501,674$ & $\$ 6,230,37$ I \\
\hline amlodipine & $5 \mathrm{mg}$ & 33.91 & 1.34 & $\$ 5,229,385$ & $\$ 207,280$ & $\$ 5,022,106$ & $\$ 7,383,800$ & $\$ 292,675$ & $\$ 7,091,125$ & $\$ 4,936,710$ \\
\hline atenolol & 50 mg & 14.37 & 0.89 & $\$ 5,153,978$ & $\$ 318,870$ & $\$ 4,835,107$ & $\$ 8,170,923$ & $\$ 505,525$ & $\$ 7,665,398$ & $\$ 4,648,452$ \\
\hline simvastatin & 40 mg & 62.51 & 4.28 & $\$ 5,362,290$ & $\$ 366,767$ & $\$ 4,995,524$ & $\$ 10,500,934$ & $\$ 718,236$ & $\$ 9,782,697$ & $\$ 4,644,054$ \\
\hline ramipril & $5 \mathrm{mg}$ & 20.00 & 4.80 & $\$ 7,217,853$ & $\$ 1,730,951$ & $\$ 5,486,902$ & $\$ 11,425,438$ & $\$ 2,739,994$ & $\$ 8,685,444$ & $\$ 4,477,859$ \\
\hline paroxetine & 20 mg & 45.14 & 5.71 & $\$ 5,940,702$ & $\$ 750,972$ & $\$ 5,189,730$ & $\$ 13,064,938$ & $\$ 1,651,556$ & $\$ 11,413,382$ & $\$ 4,289,146$ \\
\hline amlodipine & $10 \mathrm{mg}$ & 50.34 & 2.01 & $\$ 4,006,534$ & $\$ 159,965$ & $\$ 3,846,569$ & $\$ 6,004,139$ & $\$ 239,722$ & $\$ 5,764,417$ & $\$ 3,766,813$ \\
\hline & & \multicolumn{2}{|c|}{ Total for top 10 drugs } & $\$ 79,775,196$ & $\$ 10,762,275$ & $\$ 69,012,921$ & $\$ 142,131,837$ & $\$ 18,963,415$ & $\$ 123,168,421$ & $\$ 60,811,781$ \\
\hline & & \multicolumn{2}{|c|}{ Total for all 82 drugs } & $\$ 189,743,345$ & $\$ 61,175,999$ & $\$ 128,567,345$ & $\$ 347,413,255$ & $\$ 102,641,675$ & $\$ 244,771,581$ & $\$ 87,101,670$ \\
\hline
\end{tabular}

*Source: Pricing data were obtained in 201 I from the Ontario Drug Benefit Formulary, the US Department of Veterans Affairs pharmaceutical price listings and the New Zealand Pharmaceutical Management Agency Schedule. Total costs were calculated using drug utilization data from IMS Brogan PharmaStat (public utilization) and IMS Brogan Canadian CompuScript (total market utilization). 


\section{Sensitivity analyses}

These results were robust to several sensitivity analyses. First, using 2010 or 2011 exchange rates did not change my overall conclusions (not shown). Second, using the higher of the two international prices results in estimates that are, of course, smaller, but trend in the same direction: the estimated savings under the public sector scenario would have been $\$ 112$ million (versus $\$ 129$ million), and the full public coverage scenario savings would have been $\$ 59$ million (versus $\$ 87$ million). Further, the results using the prices on each formulary separately all have the same direction and substantive interpretation: the estimated savings for the public, total and full public coverage scenarios were \$77 million, \$145 million and \$56 million using only New Zealand prices, and $\$ 118$ million, \$226 million and \$74 million using only VA prices, respectively. Last, even if all these generic products were priced at $20 \%$ of the brand-name price, 70 of the 82 drugs would still be more expensive in Ontario, and savings under the public sector and full public coverage scenarios would still have been positive ( $\$ 91$ million and $\$ 49$ million, respectively).

\section{Discussion}

Over the past few years, there have been significant changes to generic pricing in Canada. Ontario has moved the farthest of any province by lowering its price ceiling to $25 \%$ of the equivalent brand name in 2010. Overall, I found that even in comparison to these price levels, generic drug prices remain substantially lower in other countries that use competitive mechanisms to set prices. If Canadians had obtained these same competitive prices for the popular drugs I studied, the reductions in unit cost would be sufficient to pay for all purchases - both public and private - for substantially less than what Ontario currently spends on its public program alone.

Purchasing drugs in Canada using more competitive processes has been proposed for many years. Virtually every recent major commission on healthcare reform has recommended that bulk purchasing and tendering strategies be used to lower Canadian drug costs (Law and Morgan 2011). While the savings from such strategies have been estimated in the billions of dollars (Morgan et al. 2007), to date they have not been widely used in Canada to purchase generic drugs. The comparator drug plans I analyzed, the US Veterans Affairs and the NZ Pharmac plans, both use competition to purchase on behalf of large patient populations ( 8.1 million and 4.4 million people, respectively). However, these patient populations are both substantially smaller than the purchasing power that could be exercised by Ontario or by cross-provincial purchasing coalitions. Beyond market size, there are other differences between jurisdictions that Canadian policy makers should consider when designing and implementing tendering approaches, including intellectual property laws and pharmacy reimbursement practices (Law and Kratzer 2012).

\section{Potential limitations}

My estimates use the per-unit ingredient cost of generic drugs, and thus the full public coverage scenario does not include other important categories of expenditures and savings. For expenditures, my estimates do not include the additional utilization, dispensing fees and markups that would fall to the public plan if full coverage were introduced. It is worth noting that public markups and dispensing 
fees are typically lower, so this shift would likely represent a net cost savings in societal terms (Secor Consulting 2010). In contrast, I also did not estimate the potential savings if the full public coverage scenario induced switching from more expensive medicines to lower-cost generics. Similarly, my estimates do not include potential savings in other areas of the healthcare system through the improved adherence and outcomes that lower-priced medicines might promote (Dhalla et al. 2009).

\section{Conclusion}

For many years, Canadians have paid for generic drugs using regulated percentages of the equivalent brand name. Despite a very controversial round of cuts to these percentages in nearly every province over the past three years, I found that drug plans and patients in Ontario - the province with the lowest prices in Canada - will still pay nearly a quarter-billion dollars every year more than they would under international best prices. I also found that alternative pricing mechanisms could save enough to introduce full public coverage for many generics, and save millions of dollars in the process (Law and Morgan 2011). Such an approach would benefit drug plans through lower prices, improve patient health through reducing cost-related non-adherence and free available public healthcare funds for non-drug expenses.

\section{ACKNOWLEDGEMENTS}

The author thanks IMS Brogan for providing data for this analysis, and Alison Ytsma and Lucy Cheng for their assistance in collecting pricing data. Data acquisition for this study was supported by an operating grant from the Canadian Institutes of Health Research (MOP-221233, "For Whom the Bill Tolls: Private Drug Insurance in Canada," P.I. Michael Law). Dr. Law receives salary support through a New Investigator Award from the Canadian Institutes of Health Research and a Career Investigator Award from the Michael Smith Foundation for Health Research.

Correspondence may be directed to: Michael R. Law, Centre for Health Services and Policy Research, University of British Columbia, 201-2206 East Mall, Vancouver, BC V6T 1Z3; tel.: 604-822-3514; fax:604-822-5690; e-mail: mlaw@chspr.ubc.ca.

\section{REFERENCES}

Bank of Canada. 2011. Monthly and Annual Average Exchange Rates. Retrieved December 19, 2012. <http://www.bankofcanada.ca/rates/exchange/exchange-rates-in-pdf $>$.

Board on Health Care Services. 2000. Description and Analysis of the VA National Formulary. Washington, DC: Institute of Medicine. Retrieved December 19, 2012. <http://www.iom.edu/Reports/2000/Description-and-Analysis-of-the-VANational-Formulary.aspx $>$.

Canadian Generic Pharmaceutical Association. 2011. "Release of Canadian Prescription Drug Sales Information Highlights Increasing Value of Generic Medicines." Retrieved December 19, 2012. <http://www.canadiangenerics.ca/en/news/ mar_29_11.asp>.

Canadian Institute for Health Information (CIHI). 2011. Health Care Cost Drivers: The Facts. Ottawa: Author. Retrieved December 19, 2012. <https://secure.cihi.ca/free_products/health_care_cost_drivers_the_facts_en.pdf >.

Competition Bureau Canada. 2007. Generic Drug Sector Study. Ottawa: Government of Canada. Retrieved December 19, 2012. <http://competitionbureau.gc.ca/eic/site/cb-bc.nsf/eng/02495.html>. 


\section{Money Left on the Table: Generic Drug Prices in Canada}

Competition Bureau Canada. 2008. Benefiting from Generic Drug Competition in Canada: The Way Forward. Ottawa: Government of Canada. Retrieved December 19, 2012. <http://competitionbureau.gc.ca/eic/site/cb-bc.nsf/eng/02753.html>.

Dhalla, I., M. Smith, N. Choudhry and A. Denburg. 2009. “Costs and Benefits of Free Medications After Myocardial Infarction." Healthcare Policy 5(2): 68-86.

Government of British Columbia. 2012 (February 29). "Lower Drug Prices to Benefit Patients, Health System." News release. Retrieved December 19, 2012. <http://www.newsroom.gov.bc.ca/2012/02/lower-drug-prices-to-benefit-patients-healthsystem.html>.

Government of Ontario. 2011. Ontario Drug Benefit Formulary/Comparative Drug Index. Retrieved December 19, 2012. <https://www.healthinfo.moh.gov.on.ca/formulary/index.jsp>.

Guertin, J.R., C.A. Jackevicius, J.L. Cox, K. Humphries, L. Pilote, D.Y. So et al. 2011.“'The Potential Economic Impact of Restricted Access to Angiotensin-Receptor Blockers." Canadian Medical Association Journal 183(3): e180-e186. doi: 10.1503/ cmaj.100787.

IMS Brogan. 2011. “Generic Dispensing Trends by Province, Canada, 2010” Retrieved December 19, 2012.

$<$ http://www.imshealth.com/deployedfiles/imshealth/Global/Americas/North\%20America/Canada/StaticFile/ GenericDispensingProvince_En_11.pdf $>$.

IMS Health. 2011. "IMS Institute Reports US Spending on Medicines Grew 2.3 Percent in 2010, to \$307.4 Billion." Retrieved May 5, 2011. <http://www.imshealth.com>.

Jackevicius, C.A., J.L. Cox, D. Carreon, J.V. Tu, S. Rinfret, D. So et al. 2009.“Long-Term Trends in Use of and Expenditures for Cardiovascular Medications in Canada." Canadian Medical Association Journal 181(1-2): e19-e28. doi: 10.1503/cmaj.081913.

Kesselheim, A.S., A.S. Misono, J.L. Lee, M.R. Stedman, M.A. Brookhart, N.K. Choudhry et al. 2008. "Clinical Equivalence of Generic and Brand-Name Drugs Used in Cardiovascular Disease: A Systematic Review and Meta-Analysis." Journal of the American Medical Association 300(21): 2514-26. doi: 10.1001/jama.2008.758.

Law, M.R., L. Cheng, I.A. Dhalla, D. Heard and S.G. Morgan. 2012."The Effect of Cost on Adherence to Prescription Medications in Canada." Canadian Medical Association Journal 184(3): 297-302. doi: 10.1503/cmaj.111270.

Law, M.R. and J. Kratzer. 2012. “The Road to Competitive Generic Drug Prices in Canada” Canadian Medical Association Journal. doi: $10.1503 /$ cmaj.121367.

Law, M.R. and S.G. Morgan. 2011. "Purchasing Prescription Drugs in Canada: Hang Together or Hang Separately" Healthcare Policy 6(4): 22-26.

Morgan, S., G. Hanley, M. McMahon and M. Barer. 2007."Influencing Drug Prices through Formulary-Based Policies: Lessons from New Zealand." Healthcare Policy 3(1): 1-20.

Morgan, S.G. 2004. "Sources of Variation in Provincial Drug Spending," Canadian Medical Association Journal 170(3): 329-30.

Morgan, S.G., M.L. Barer and J.D. Agnew. 2003. "Whither Seniors' Pharmacare: Lessons from (and for) Canada." Health Affairs 22(3): 49-59. doi: 10.1377/hlthaff.22.3.49.

Moulton, D. 2011. “Provincial Squeeze on Generic Prices Continues.” Canadian Medical Association Journal 183(14): e1049_ e1050. doi: 10.1503/cmaj.109-3966.

New Zealand Pharmaceutical Management Agency. 2011."Purchasing Medicines." Retrieved December 19, 2012. <http:// www.pharmac.govt.nz/2011/09/16/05PURCHASING_MEDS.pdf > .

Patented Medicine Prices Review Board (PMPRB). 2006. Non-Patented Prescription Drug Prices Reporting: Canadian and Foreign Price Trends. Ottawa: Author.

Patented Medicine Prices Review Board (PMPRB). 2010. Generic Drugs in Canada: Price Trends and International Comparisons, 2007. Ottawa: Author. Retrieved December 19, 2012. <http://www.pmprb-cepmb.gc.ca/english/View. asp? $=14198 \mathrm{mp}=124>$.

Pharmaceutical Management Agency. 2011. Online Schedule. Retrieved December 19, 2012. <http://www.pharmac.govt.nz/ Schedule>.

Pharmacy Benefits Management Services. 2012. Drug Pharmaceutical Prices. Washington: US Department of Veterans Affairs. Retrieved December 19, 2012. <http://www.pbm.va.gov/DrugPharmaceuticalPrices.aspx>.

Secor Consulting. 2010. Generic Drug Pricing and Access in Canada: What Are the Implications? Toronto: Health Council of Canada. 